\title{
ANALISIS PERBANDINGAN PENERIMAAN PPN \&PPn BM SEBELUM DAN SESUDAH PENERAPAN METODE E-FILING PADA KPP PRATAMA SERANG
}

\author{
Iroh Rahmawati \\ Universitas Banten Jaya \\ Serang, Indonesia \\ irohrahma@gmail.com
}

\begin{abstract}
From an economic point of view, taxes are state revenues used to direct people's lives towards prosperity. Tax as a driving force for people's economic life. By applying the e-filling method in the PPN \& PPn BM tax service system, it is expected that state revenue can increase. The purpose of this study was to analyze the comparison of acceptance of PPN $\&$ PPn BM before and after the e-filling method was applied. Data analysis technique used paired test sample T-test with the help of SPSS. To find out whether or not the hypothesis was accepted, a comparison of tcount $(-2,392)$ and $t$ table $(2,201)$ was used. Based on calculations it is known that there was no significant difference in the amount of PPN \& PPn BM receipts before and after the e-filling method was applied.
\end{abstract}

Keywords : E-filling, Tax, PPN \& PPn BM revenue

\section{PENDAHULUAN}

Kontribusi pajak Dalam Anggaran Pendapatan dan Belanja Negara (APBN) dari tahun ke tahun semakin meningkat jumlahnya. Kenyataan ini membuktikan bahwa wujud partisipasi masyarakat yaitu wajib pajak Nampak nyata dalam pembangunan.

Wujud partisipasi ini harus dibarengi dengan jaminan hak-hak wajib pajak sebagaimana yang tertuang dalam Undangundang perpajakan. Hak dan kewajiban harus seimbang sehingga keadilan dapat diwujudkan. Hak Negara untuk memungut pajak membawa konsekuensi bahwa Negara berkewajiban untuk meningkatkan system pelayanan perpajakan.

Sebagai Negara yang sedang berusaha keluar dari keterbelakangan dan ketergantungan kepada sumber daya alam, Indonesia mulai menggalakan pajak sejak reformasi digulirkan. Kesadaran bahwa tidak akan bisa selamanya mengandalkan ekspor minyak dan gas bumi untuk penerimaan Negara, membuat pemerintah Indonesia lebih giat dalam mengusahakan peningkatan penerimaan pajak. Mengingat betapa pentingnya peran pajak dalam meningkatkan kemampuan finasial Negara. Salah satu cara yang sedang coba dikembangkan oleh Direktorat Jendral Pajak adalah penerapan 
teknologi informasi dalam proses pelayanan perpajakan. Dengan fasilitas ini, Wajib Pajak mendapatkan kemudahan antara lain dapat melakukan fasilitas pembayaran pajak melalui online banking dan pelaporan surat pemberitahuan (SPT) melalui media yang juga terhubung secara online. Sehingga Wajib Pajak tidak perlu lagi melakukan serangkaian prosedur manual seperti yang selama ini dilakukan.

Pelaporan SPT Masa PPN harus dilampiri dengan faktur atau pajak keluaran dan pajak masukan, jumlah daftar ini bisa mencapai ribuan lembar tergantung dari banyaknya transaksi yang tejadi dalam satu bulan sehingga laporan SPT Masa PPN menjadi sangat tebal dengan lampiran. Keadaan ini selain menyulitkan PKP dalam mempersipakan SPT Masanya juga menimbulkan kesulitan bagi KPP untuk memproses dan menyimpannya.

Kondisi yang demikian melatarbelakangi aparat perpajakan Indonesia melakukan inovasi dalam pelayanannya terhadap KPP berupa kemudahan pelaporan SPT Masa PPN dan PPnBM secara online.

Dijadikannya PPN dan PPnBM sebagai jenis pajak pertama yang menggunakan implementasi system ini, selain didasarkan pada banyaknya jumlah lampiran, juga dikarenakan kompleksitas jenis pajak ini yang lebih tinggi dibandingkan dengan yang lain. Sehingga bila system ini berhasil diterapkan pada PPN dan PPn BM, maka akan menjadi lebih mudah untuk diterapkan pada jenis pajak lain yang tidak terlalu kompleks.

Melalui keputusan Direktorat Jendral Pajak No Kep.315/PJ/2002 yang dikelurkan di Jakarta pada tanggal 13 Juni 2002 dan telah diubah dengan Keputusan Direktorat Jendral Pajak No KEP-344/PJ/2002, pemerintah memberlakukan system pelaporan SPT Masa PPN yang baru. Surat Keputusan tersebut memaparkan tentang pelaksanaan uji coba penyampaian Surat Pemberitahuan (SPT) masa secara online khusus untuk Pajak Pertambahan Nilai (PPN) dan Pajak Penjualan Barang Mewah (PPnBM) dengan metode $e$ filing atau pengisian SPT secara elektronik. Uji coba e-filing tersebut mulai efektif diberlakukan pada SPT Masa PPN dan PPn BM bulan Juni 2002 yang dilaporkan pada bulan Juli 2002.

Tujuan penelitian ini adalah untuk mengetahui perbandingan penerimaan PPN dan PPnBM sebelum dan sesudah diterapkannya metode $e$-filing .

Pajak Penjualan barang mewah adalah pajak yang dikenakan pada barang yang termasuk dalam golongan mewah menurut Undang undang yang mengaturnya.

Pajak Penjualan Barang Mewah merupakan salah satu contoh pajak yang memiliki fungsi regulator (pengatur) untuk menekan pola konsum.si masyarakat yang tidak produktif. Selain itu, pemerintah 
PROGRESS

Jurnal Pendidikan, Akuntansi dan Keuangan

Universitas Banten Jaya

memberlakukan pajak ini dalam usaha untuk menyeimbangkan pembebanan pajak kepada masyarakat yang berpenghasilan tinggi dan masyarakat yang berpenghasilan rendah.

Berbeda dengan Pajak Pertambahan Nilai yang pengenaanya dilakukan pada setiap mata rantai produksi. Pajak penjualan Barang Mewah hanya dikenakan satu kali saat penyerahan Barang Kena Pajak (BKP) yang tergolong mewah untuk pengusaha yang menghasilkan atau pada saat impor.

Pajak penjualan Barang Mewah tidak dapat dikenakan sendiri tanpa adanya pungutan Pajak Pertambahan Nilai karena pada hakikatnya Pajak Penjualan barang Mewah adalah pajak tambahan yang dikenakan kepada objek Pajak Pertambahan Nilai yang tergolong dalam kategori barang mewah. Yang dimaksud dengan Barang Kena Pajak yang Tergolong Mewah tersebut adalah sebagai berikut :

1. Barang tersebut bukan merupakan barang kebutuhan pokok

2. Barang tersebut dikonsumsi Oleh masyarakat tertentu

3. Pada umumunya barang tersebut dikonsumsi oleh masyarakat berpenghasilan tinggi.

4. Barang tersebut dikonsumsi untuk menunjukan status.

5. Apabila dikonsumsi dapat merusak kesehatan dan moral masyarakat serta mengganggu ketertiban masyarakat, seperti minuman yang mengandung alkohol

$$
\text { Pembayaran pajak dengan }
$$
menggunakan metode online banking dilaksanakan oleh pemerintah bersama-sama dengan beberapa bank swasta dan Bank BUMN di Indonesia. Sedangkan pelaporan SPT masa secara online dengan metode $e$ filing dilaksanakan pemerintah melalui Direktorat Jendral Pajak, dengan membangun suatu sistem dan program aplikasi terlebih dahulu.

Metode $e$-filing menggunakan program aplikasi yang dapat dipakai pada komputer Wajib Pajak dengan kualifikasi tertentu. Dengan program ini, Wajib Pajak dapat mengirimkan berkas induk dan lampiran SPT Masa PPN dan PPn BM secara online langsung kepada Direktorat Jendral Pajak. Tujuannya adalah untuk meningkatkan proses pelayanan perpajakan terhadap Wajib Pajak dan meningkatkan jumlah penerimaan pajak PPN \& PPn BM. Sehingga penerimaan negara dari sektor pajak terutama jenis pajak PPN \& PPn BM.

Mekanisme umum yang dilakukan sehubungan dengan pelaporan SPT dengan $E$ filing dimulai dengan pendaftaran Pengusaha Kena Pajak (PKP) sebagai peserta pelaporan online. Setelah mendaftar, PKP akan menerima paket program SPI' Masa PPN dan PPn BM dalam bentuk disket atau media Iain beserta user ID dan password awal sebagai 
tanda bukti terdaftar. Kemudian, pada waktu yang diharuskan, Wajib Pajak mengirimkan eSPT (Electronic SPT) yang telah diisi beserta lampirannya dengan menggunakan program aplikasi tersebut. Dan menerima berita acara pengiriman SPT Masa yang memuat Nomor Penitipan Data (NPD) saat itu juga (real time). Kewajiban Pengusaha Kena Pajak dianggap selesai bila telah mencetak SPT induk, menandatangani dan menyerahkan kepada KPP dengan di lampiri berita acara pengiriman SPT serta dokumen — dokumen Iain yang diharuskan.

Selama ini, metode yang digunakan dalam pelaporan SPT adalah mekanisme manual. Jadi Wajib Pajak diharuskan untuk mencatat, menghitung, menyetor, dan melaporkan seluruh hal yang terkait dengan kewajiban pajak kepada KPP. Sesuai dengan domisilinya, secara langsung. Cara ini menimbulkan kesulitan dan kendala baik pada Wajib Pajak maupun pada pihak fiskus (KPP). Kesulitan yang di hadapi oleh Wajib Pajak adalah kebutuhan yang tinggi atas waktu dan personel, karena ketidak praktisan metode penyampaian SPT secara manual. Sedangkan KPP yang merasa diberatkan beban pekerjaan klerikal yang sangat banyak, tingginya tingkat kesalahan pemasukan data karena human error, lamanya waktu yang dibutuhkan untuk memproses SPT Wajib Pajak sampai dengan Direktorat Jendral Pajak, serta sedikitnya jumlah penerimaan yang diperoleh dari pajak PPN \& PPn BM.

Mekanisme pelaporan SPT Masa PPN dan PPn BM yang dilaksanakan dengan cara e-filing dapat menutupi kelemahan-kelemahan yang timbul dari metode manual yang selama ini dilaksanakan. Dengan e-filing, proses pelaporan SPT dari Wajib Pajak menjadi lebih cepat dengan tingkat akurasi data yang lebih tinggi. Selain itu juga terjadi efisiensi biaya dan personal.

Namun, perkembangan teknologi selalu bersifat seperti dua sisi mata pisau. Di satu sisi, penggunaannya dapat meningkatkan efektifitas dan efisiensi organisasi, namun di sisi lain penerapannya juga dapat menimbulkan dampak negatif seperti masalah keamanan data-data dari Wajib Pajak mengingat SPT adalah salah satu dokumen pajak yang berisi informasi yang sangat penting. Demikian pula halnya dengan penerapan teknologi informasi di dunia perpajakan Indonesia berupa pelaporan SPT secara online yang tentu akan membawa berbagai dampak yang dapat mempengaruhi kinerja dunia pajak Indonesia.

\section{METODE PENELITIAN}

Populasi dalam penelitian ini adalah pajak yang terdapat pada kantor pelayanan pajak pratama serang dan sampel yang digunakan adalah jumlah penerimaan PPN \& PPn BM sebelum dan sesudah diterapkannya 
PROGRESS

Jurnal Pendidikan, Akuntansi dan Keuangan

Universitas Banten Jaya

metode e-filling, penelitian ini dilakukan dengan pendekatan study kasus menggunakan metode komparatif, yaitu suatu penelitian yang bersifat membandingkan (sugiyono, 2004:11).

Teknik penarikan sampel dalam penelitian ini menggunakan purpose sampling yaitu penarikan sampel dilakukan atas pertimbangan-pertimbangan peneliti. Dimana sampel yang dipilih harus mempunyai kriteriakriteria sebagai berikut, :

1. Jumlah penerimaan pajak PPN \& PPn BM yang menggunakan metode $e$-filing .

2. Jumlah penerimaan pajak PPN \& PPn Bm yang tidak menggunakan metode $e$-filing.

Pengolahan data untuk pengujian hipotesis dilakukan dengan menggunakan paired sampel T-test.

\section{PEMBAHASAN}

Tabel 1 Jumlah Penerimaan PPn \& BM

(Dalam jutaan rupiah)

\begin{tabular}{lrr}
\hline \multicolumn{1}{c}{ Bulan } & \multicolumn{2}{c}{ PPN \& PPn BM } \\
& $\begin{array}{l}\text { Sebelum } \\
\text { E-filing }\end{array}$ & \multicolumn{1}{l}{$\begin{array}{l}\text { Setelah } \\
\text { E-filing }\end{array}$} \\
\hline Januari & 38.789 .45 & 40.125 .56 \\
Februari & 36.856 .78 & 37.412 .56 \\
Maret & 36.587 .12 & 37.476 .77 \\
April & 38.512 .56 & 41.534 .67 \\
Mei & 32.158 .45 & 33.824 .78 \\
Juni & 33.897 .54 & 34.859 .25 \\
Juli & 26.820 .45 & 28.520 .45 \\
Agustus & 36.759 .32 & 38.455 .49 \\
September & 37.452 .38 & 40.626 .08 \\
Oktober & 26.052 .12 & 41.983 .93 \\
November & 30.879 .78 & 32.631 .40 \\
Desember & 27.546 .67 & 29.509 .76 \\
Total & $\mathbf{4 0 2 . 3 1 2 . 6 2}$ & $\mathbf{4 3 6 . 9 6 0 . 7 0}$ \\
\hline
\end{tabular}

Sumber : KPP Pratama Serang

Dari tabel 1 dapat diketahui bahwa jumlah penerimaan PPN \& PPn BM sebelum diterapkannya metode $e$-filling adalah sebesar Rp. 402.312.620,-, sedangkan jumlah penerimaan PPN \& PPn BM setelah diterapkannya metode $e$-filling adalah sebesar Rp. 436.960.700,-.

Untuk mengetahui apakah suatu variable atau data yang digunakan berdistribusi normal atau tidak, maka terlebih dahulu dilakukan uji normalitas dengan OneSampel Kolmogorov-Smirnov Test.

Tabel 2 Uji Normalitas

\section{One Sampel Kolmogorov-Smirnov Test}

\begin{tabular}{|c|c|c|c|}
\hline & & $\begin{array}{c}\text { Penerimaan } \\
\text { sebelum } \\
e \text {-filing }\end{array}$ & $\begin{array}{c}\text { Penerimaan } \\
\text { sesudah } \\
e \text {-filing }\end{array}$ \\
\hline $\mathrm{N}$ & & 12 & 12 \\
\hline Normal & Mean & 33526.0519 & 36413.3917 \\
\hline Parameters $(a, b)$ & Std. Deviation & 4714.49791 & 4557.34161 \\
\hline Most Extreme & Absolute & .242 & .170 \\
\hline \multirow[t]{2}{*}{ Difeferences } & Positive & .148 & .111 \\
\hline & Negative & -.242 & -.170 \\
\hline $\begin{array}{l}\text { Kolmogorov- } \\
\text { Semirnov }\end{array}$ & $\mathrm{Z}$ & .838 & .589 \\
\hline $\begin{array}{l}\text { Asymp.Sig. (2- } \\
\text { tailed) }\end{array}$ & & .484 & .878 \\
\hline
\end{tabular}

Dari hasil Kolmogorov-Smirnov diatas didapat nilai $\mathrm{Z}$ masing-masing variabel adalah 0,838 untuk penerimaan PPN \& PPn BM sebelum diterapkannya metode e-filing dan 0,589 untuk penerimaan PPN \& PPn BM setelah diterapkannya metode e-filing, dan nilai pada masing-masing Asymp.Sig. (2tailed) adalah 0,484 dan 0,878, ini menunjukan bahwa nilai tersebut diatas 0,05 $(5 \%)$, artinya data yang digunakan dalam penelitian ini berdistribusi normal. 
Tabel 3 Paired Sampels Statstics

\begin{tabular}{|c|c|c|c|c|}
\hline & Mean & $\mathrm{N}$ & $\begin{array}{l}\text { Std } \\
\text { Deviation }\end{array}$ & $\begin{array}{l}\text { Std Error } \\
\text { Mean }\end{array}$ \\
\hline $\begin{array}{l}\text { Penerimaan } \\
\text { sebelum } e \text {-filing }\end{array}$ & 33526.0519 & 12 & 4714.49791 & $\begin{array}{l}1360.958 \\
832\end{array}$ \\
\hline $\begin{array}{l}\text { Penerimaan } \\
\text { sesudah } e \text {-filing }\end{array}$ & 36413.3917 & 12 & 4557.34161 & $\begin{array}{l}1315.591 \\
20\end{array}$ \\
\hline
\end{tabular}

Sumber : Output SPSS

Interpretasi output paired sample statistics, penerimaan sebelum diterapkan metode $e$-filing rata-rata jumlah penerimaan PPN \& PPn BM sebesar 33526,0519, standar deviasi 4714,49791, dan rata rata standar error 1360,95832. Sedangkan jumlah penerimaan PPN \& PPn BM setelah diterapkannya metode e-filing rata-rata adalah sebesar 36413,3917, standar deviasi 4557,34161, dan rata - rata standar error 1315,59120. Dibandingkan sebelumnya, terjadi kenaikan rata-rata jumlah penerimaan PPN \& PPn BM setelah diterapkannya metode $e$-filing yang diadopsi oleh Direktorat Jendral Pajak, yang diciptakan untuk memudahkan cara wajib pajak dalam memenuhi kewajiban perpajakannya.

Tabel 4 Paired Samples Correlations

\begin{tabular}{lccc}
\hline & $\mathrm{N}$ & Correlations & Sig. \\
\hline Penerimaan & & & \\
sebelum $e-$ & & & \\
filing & 12 & .594 & .042 \\
Penerimaan & & & \\
sesudah $e$-filing & & & \\
\hline
\end{tabular}

Sumber : Hasil output SPSS

Interpretasi output paired samples correlations. Korelasi antara penerimaan PPN \& PPn BM sebelum diterapkannya metode $e$ filing dan sesudah diterapkannya metode $e$ filing adalah $\mathrm{r}=0,594$ dengan nilai $\mathrm{p}$ atau tampak pada kolom sig. 0,042, menunjukan bahwa korelasi jumlah penerimaan PPN \& PPn BM sebelum diterapkannya metode $e$ filing dan sesudah diterapkannya metode $e$ filing sangat kuat karena $\mathrm{r}$ mendekati 1 dan signifikan pada taraf kepercayaan 95\% karena $\mathrm{p}<0,05$.

Tabel 5 Paired Samples Test

\begin{tabular}{|c|c|c|c|c|c|c|c|c|}
\hline & \multicolumn{5}{|c|}{ Paired Differences } & \multirow[t]{2}{*}{$\mathrm{t}$} & \multirow[t]{2}{*}{$\mathrm{df}$} & \multirow[t]{2}{*}{ Sig (2-tailed) } \\
\hline & Mean & Std Deviation & $\begin{array}{ll}\text { Std. } & \text { Error } \\
\text { Mean } & \end{array}$ & $\begin{array}{l}\text { 95\% Confidance } \\
\text { the Difference }\end{array}$ & Interval of & & & \\
\hline $\begin{array}{l}\text { Penerimaan sebelum } e \text { - } \\
\text { filing }\end{array}$ & -2887.33975 & 4180.72648 & 1206.87178 & -5543.64663 & -231.03287 & 2.392 & 11 & .036 \\
\hline $\begin{array}{l}\text { Penerimaan sesudah } e \text { - } \\
\text { filing }\end{array}$ & & & & & & & & \\
\hline
\end{tabular}

Sumber : Hasil output SPSS

Interpretasi paired samples test untuk menguji apakah ada perbedaan yang signifikan jumlah penerimaan PPN \& PPn
BM sebelum dan sesudah diterapkannya metode e-filing, maka pengambilan keputusan dapat dilakukan dengan cara 
membandingkan nilai $\mathrm{t}$ hitung dengan $\mathrm{t}_{\text {table. }}$ Tampak dalam table 5, bahwa $t_{\text {hitung }}$ sebesar 2,392 dan pada distribusi nilai t, yaitu pada taraf kepercayaan $95 \%(\mathrm{u}=5 \%$ dan karena uji t bersifat dua sisi, maka nilai a yang dirujuk adalah $\mathrm{u} / 2=5 \%=$ 0,025) dan derajat bebas (df) n-1 12-1=11, sehingga besarnya $t_{\text {table }} 2,201$. Karena $t_{\text {hitung }}$ $<$ maka Ho diterima dan Ha ditolak, artinya tidak terdapat perbedaan secara signifikan, jumlah penerimaan PPN \& PPn BM sebelum diterapkannya metode $e$ filing dan sesudah diterapkannya metode $e$-filing. Setelah diterapkannya metode $e$ filing jumlah penerimaan PPN \& PPn BM dalam sample kerjanya meningkat, tetapi meningkatnya jumlah penerimaan PPN \& PPn BM karena penerapan metode $e$-filing ini tidak dapat diberlakukan untuk seluruh populasi dimana sample diambil. Hasil inipun dapat diperkuat dengan jumlah penerimaan PPN \& PPn BM seperti yang terdapat pada tabel 1 .

Hasil penelitian ini sejalan dengan penelitian yang dilakukan oleh Novien dan Rury pada tahun 2019 dengan judul efektifitas penggunaan e-filing atas penerimaan pajak pada KPP Pratama Medan Belawan bahwa penerimaan pajak mengalami peningkatan tetapi belum mencapai jumlah yang diharapkan.

Jika dikaitkan dengan teori penelitian ini adalah Technologi
Acceptance Model (TAM) yang menjelaskan bahwa suatu model untuk memprediksi dan menjelaskan bagimana pengguna teknologi menerima dan menggunakan teknologi tersebut dalam pekerjaan individual pengguna. Tujuan dari Technologi Acceptance Model (TAM) ini adalah untuk menjelaskan sikap individu terhadap pengunaan suatu teknologi. Sikap individu maupun reaksi yang muncul dari penerimaan teknologi tersebut dapat bermacammacam diantaranya dapat digambarkan dengan intensitas maupun tingkat penggunaan teknologi tersebut. (Novie dan Rury 2019) Menurut Pratama (2008) dalam Gita (2010), penerimaan penggunaa maupun pemakai teknologi informasi menjadi bagian dari riset penggunaan teknologi informasi, sebab sebelum digunakan dan diketahui kesuksesannya, terlebih dahulu dipastikan tentang penerimaan maupun penolakkan atas penggunaan teknologi informasi tersebut. Penerimaan pengguna teknologi informasi merupakan faktor penting dalam penggunaan dan pemanfaatan system informasi yang dikembangkan. Penerimaan pengguna teknologi informasi sangat erat kaitannya dengan variasi permasalahan pengguna dan potensi imbalan yang diterima jika teknologi 
informasi diaplikasikan dalam aktivitas pengguna dengan aktivitas perpajakan.

Pengguna yang dimaksud dalam penelitian ini adalah fiscus dan wajib pajak orang pribadi (WPOP) serta teknologi informasi yang dimaksud adalah e-filling.

\section{KESIMPULAN}

Proses pelaporan SPT Masa PPN \& PPn BM dengan menggunakan metode $e$ filing secara umum mendapatkan tanggapan yang positif dari pihak-pihak yang terkait. Banyak pihak yang merasa sangat terbantu dengan adanya fasilitias ini. Metode pelaporan SPT secara online dengan metode dirasakan dapat menutupi kelemahan- kelemahan yang ada dalam pelaporan SPT dengan metode manual. Dengan $e$-filing, proses pelaporan SPT dari Wajib Pajak menjadi lebih cepat dengan tingkat akurasi data yang lebih tinggi. Selain itu juga terjadi efesiensi biaya dan personil karena program aplikasi dirancang untuk e-filing sifatnya mudah untuk digunakan (user vriendly).

Dapat diketahui bahwa jumlah penerimaan PPN \& PPn BM sebelum diterapkannya metode $e$-filing adalah sebesar RP. 402.312.620,- sedangkan jumlah penerimaan PPN \& PPn BM setelah diterapkan metode $e$-filing adalah sebesar RP. 436.960.700,-. Dari hasil penelitian, diketahui bahwa tidak terdapat perbedaan secara signifikan, jumlah penerimaan PPN \& PPn BM sebelum dan sesudah diterapkannya metode e-filing pada KPP Pratama Serang.

Penelitian ini hanya menekankan pada jumlah penerimaan PPN \& PPn BM. Penelitian selanjutnya dapat mencoba pada dimensi Iain seperti kepatuhan Wajib Pajak dalam menyampaikan kewajiban perpajaknnya, dan instrumen tidak terfokus terhadap PPN \& PPn BM bisa dengan jenis pajak pajak yang Iain.

\section{DAFTAR PUSTAKA}

Buku

Arikunto, Suharsimi. 1999. Prosedur Penelitian Suatu Pendekatan Praktek. Jakarta : Rineka Cipta.

Bodnar, George H. 2003. Sistem Informasi Akuntansi. Jakarta : PT. Indeks.

Bohari. 1999. Pengantar Hukum Pajak. Jakarta : PT. Raja Grafindo Persada.

Brotodiharjo, Santoso. 2003. Pengantar Ilmu Hukum Pajak. Bandung: Refika Aditama.

Diana, Anstasia, dan Lilis Setiawati. 2004. Perpajakan Indonesia. Yogyakarta: Andi.

Fahmi. 2004. "Penggunaan Teknologi Informasi Berdasarkan Aspek Prilaku (Behavioral Aspect) ". USU digital library.

Hanson, Ward. 2000. Pemasaran Internet. Jakarta : Salemba Empat. 
J Supranto. 2003. Melode Penelitian Hukum dan Slalistik. Jakarta : Rineka Cipta.

Keraf. Gorys. 1984. Komposisi. Ende Flores : Nusa Indah.

Mardiasmo. 2001. Perpajakan. Yogyakarta: Andi Yogyakarta

Mcleod Jr, Raymond, dan George Schell. 2002. Sistem Informasi Manajemen. Jakarta: Raja Grafindo Persada.

Nazir, M. 1999. Metode Penelitian. Jakarta: Ghalia Indonesia.

Resmi, Siti. 2005. Perpajakan Teori dan Kasus. Jakarta: Salemba Empat.

Suandy, Early. 2002. Perpaiakan di Lengkapi Dengan Latihan Soal. Jakarta •

Sujianto. Agus Eko. 2007. Aplikasi Statistik Dengan SPSS Untuk Pemula. Jakarta • Prestasi Pustaka Publiser.

Sunarto. 2005. Paiak dan Retribusi Daerah. Yogyakarta : Amus.

Triton. 2006. SPSS 13.0 Terapan Riset Statistik Parametrik. Yogyakarta: Andi.

Umar, Husein. 2001. Riset Akuntansi (Dilengkapi Dengan Panduan Membuat Skripsi Dan Empat Bahasan Kasus Bidang Akuntansi). Jakarta Gramedia Pustaka Utama.

2008. Desain Penelitian Akuntansi

Keprilakuan. Jakarta : PT. Raja Grafindo.

Waluyo, dan Wirawan Ilyas. 2005.

Perpajakan Indonesia. Jakarta: Salemba empat.
Buku Terjemah

Cooper, Donald R. 1996. Metode Penelitian Bisnis, terj. Widyono Soetjipto dan Uka Wikarya.

Scott, George M. 2002. Prinsip - prinsip System Informasi Manajemen, terj. Achmad Nashir Budiman. Jakarta : PT. Raja Grafindo Persada.

Jurnal

Rialdy Novien, Septiara, Rury Alfika 2019. Analisis Efektivitas Penggunaan E-filing atas Penerimaan Pajak Pada KPP Pratama Medan Belawan. Festival Riset Ilmiah Manajemen \& Akuntansi (FRIMA) 2019.

Maharsi, Sri. 2000. "Pengaruh Perkembangan Teknologi Informasi terhadap Bidang Akuntansi Manajemen". Jurnal Akuntansi \& Keuangan Vol. 2, No. 2, FE. Universitas Kristen Petra.

Internet

Http : //www.Pajak.go.id

Undang-Undang

Undang - undang RI No. 16 tahun 2000 tentang Ketentuan Umum dan Tatacara Perpaj akan.

Undang - undang RI No. 18 tahun 2000 tentang Pajak Pertambahan Nilai Barang \& Jasa, dan Pajak Penjualan Barang Mewah. 